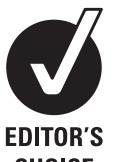

CHOICE
${ }^{1}$ Thoraxzentrum Ruhrgebiet, Department of Respiratory and Infectious Diseases, EVK Herne and Augusta-Kranken-Anstalt Bochum, Germany ${ }^{2}$ Division of Gastroenterology, Hepatology and Infectious Diseases, Jena University Hospital, Jena, Germany ${ }^{3}$ Department of Respiratory Medicine, Maastricht University Medical Centre, The Netherlands

${ }^{4}$ Medical Clinic, Infectious Diseases and Respiratory Medicine, Charité - Berlin University, Berlin, Germany 5Diakoniekrankenhaus, Respiratory Clinic Unterstedt, Rotenburg an der Wümme, Germany

${ }^{6}$ Lungenklinik Heckeshorn, Helios Klinikum Emil von Behring, Berlin, Germany ${ }^{7}$ Department of Respiratory Medicine, Hannover University, Hannover, Germany

\section{Correspondence to} Prof Santiago Ewig,

Thoraxzentrum Ruhrgebiet, Kliniken für Pneumologie und Infektiologie, EVK Herne und Augusta-Kranken-Anstalt Bochum, Bergstrasse 26, 44791 Bochum, Germany; sewig@versanet.de

Received 16 June 2011 Accepted 13 October 2011 Published Online First

5 November 2011

\title{
Nursing-home-acquired pneumonia in Germany: an 8-year prospective multicentre study
}

\author{
Santiago Ewig, ${ }^{1}$ Benjamin Klapdor, ${ }^{1}$ Mathias W Pletz, ${ }^{2}$ Gernot Rohde, ${ }^{3}$ \\ Hartwig Schütte, ${ }^{4}$ Tom Schaberg, ${ }^{5}$ Torsten T Bauer, ${ }^{6}$ Tobias Welte, ${ }^{7}$ for the CAPNETZ \\ study group
}

\section{ABSTRACT}

Objective To determine differences in aetiologies, initia antimicrobial treatment choices and outcomes in patients with nursing-home-acquired pneumonia (NHAP) compared with patients with community-acquired pneumonia (CAP), which is a controversial issue. Methods Data from the prospective multicentre Competence Network for Community-acquired pneumonia (CAPNETZ) database were analysed for hospitalised patients aged $\geq 65$ years with CAP or NHAP. Potential differences in baseline characteristics, comorbidities, physical examination findings, severity at presentation, initial laboratory investigations, blood gases, microbial investigations, aetiologies, antimicrobial treatment and outcomes were determined between the two groups.

Results Patients with NHAP presented with more severe pneumonia as assessed by CRB-65 (confusion, respiratory rate, blood pressure, 65 years and older) score than patients with CAP but received the same frequency of mechanical ventilation and less antimicrobial combination treatment. There were no clinically relevant differences in aetiology, with Streptococcus pneumoniae the most important pathogen in both groups, and potential multidrug-resistant pathogens were very rare $(<5 \%)$. Only Staphylococcus aureus was more frequent in the NHAP group ( $n=12,2.3 \%$ of the total population, $3.1 \%$ of those with microbial sampling compared with $0.7 \%$ and $0.8 \%$ in the CAP group, respectively). Short-term and long-term mortality in the NHAP group was higher than in the CAP group for patients aged $\geq 65$ years $(26.6 \%$ vs $7.2 \%$ and $43.8 \%$ vs $14.6 \%$, respectively). However, there was no association between excess mortality and potential multidrug-resistant pathogens.

Conclusions Excess mortality in patients with NHAP cannot be attributed to a different microbial pattern but appears to result from increased comorbidities, and consequently, pneumonia is frequently considered and managed as a terminal event.

\section{INTRODUCTION}

The epidemiology of community-acquired pneumonia (CAP) has undergone significant changes in the past few decades. Patients with CAP present at an increasingly older age and with severe disabilities. Mortality in these patients is usually high, reaching up to $30 \% .{ }^{12}$

As a consequence, CAP 'in the elderly' ${ }^{3-8}$ and 'in the very elderly' 9 has attracted considerable interest in the investigation of the disease. In particular,

\section{Key messages}

What is the key question?

- Nursing-home-acquired pneumonia (NHAP) is associated with considerably higher mortality than community-acquired pneumonia (CAP).

- Whether this higher mortality rate is related to different aetiologies including potential multidrug resistant (MDR) pathogens and consequently inadequate initial antimicrobial coverage remains a controversial issue.

What is the bottom line?

- NHAP does not differ from CAP in terms of aetiology and excess mortality is not related to the inadequate treatment of potential MDR pathogens.

- Excess mortality results from higher comorbidities and pneumonia frequently being considered and managed as a terminal event of advanced age and poor functional status.

Why read on?

- NHAP is a frequent condition.

- Understanding the reasons for excess mortality will allow adequate management of these patients.

patients living in nursing homes were identified as those with the highest mortality. ${ }^{10-12}$ Data from the USA indicate an excess of multidrug resistant (MDR) pathogens in patients with chronic healthcare contacts, and patients with 'nursinghome-acquired pneumonia' (NHAP) were included under the concept of 'healthcare-associated pneumonia' (HCAP). ${ }^{13} 14$

The HCAP concept has been subject to criticism. Whereas there is no doubt that older patients and those with disabilities have an increased mortality, the main hypothesis that MDR pathogens account for this excess mortality remains unproven. Moreover, leading criteria for HCAP, including severe immunosuppression and recent hospitalisation, remain questionable. Patients with severe immunosuppression form a distinct group and should not be included under the concept of HCAP. Recently hospitalised patients are clearly at risk from MDR pathogens but should be regarded and managed as patients with nosocomial pneumonia. ${ }^{15}$ If this 
rearrangement is accepted, the only remaining core group of HCAP is NHAP. ${ }^{16}$

We therefore investigated the clinical characteristics, microbial patterns and outcomes of patients with NHAP included on the large prospective Competence Network for Communityacquired pneumonia (CAPNETZ) database. In particular, we examined the association between aetiology and in-hospital mortality. Recently, we showed that there are fundamental differences in aetiology and outcome in younger patients with CAP compared with those aged $\geq 65$ years; in fact, it is a completely separate entity. ${ }^{17}$ In view of these data, we thought it most appropriate to compare hospitalised patients with CAP or NHAP aged $\geq 65$ years. This would avoid inflation of differences due to the younger patient population.

\section{METHODS}

\section{Patients}

The methodology of CAPNETZ has been reported elsewhere. ${ }^{18}$ Overall, 15 local clinical centres throughout Germany were involved. Prospective patients were those aged $\geq 18$ years with a pulmonary infiltrate diagnosed by chest x-ray, clinical symptoms of fever, cough, purulent sputum or positive auscultation. Exclusion criteria were age $<18$ years, acquired or therapeutically induced immune deficiency, active tuberculosis or a possible nosocomial genesis of infection (hospitalisation $<4$ weeks prior to infection). Cases were reported to the local participating clinical centre via a network of sentinel practices and hospitals.

The study was approved by the central and local ethics committees and written informed consent was obtained from all patients.

\section{Data collection}

Demographic, clinical, and diagnostic data were recorded using standardised web-based data sheets. The study period was 90 months from January 2002 to June 2009.

\section{Microbial investigation}

The methods applied have been described previously. ${ }^{18}$ Briefly, samples obtained included sputum and/or other respiratory secretions, blood cultures, urinary antigen testing for Streptococcus pneumoniae and Legionella pneumophila serogroup 1, serology, and nasal and pharyngeal swabs. Investigations for Mycoplasma pneumoniae were performed as described in a previous report. ${ }^{19}$ Investigations for viruses were only carried out until July 2007. All samples were immediately processed in the local participating microbiological laboratories according to the German Quality Standards in Clinical Microbiology and Infectious Diseases. ${ }^{20}$

To limit possible bias due to incomplete sampling and limited diagnostic yield of microbial investigation, pathogen frequencies were reported using the following denominators: total population; cases with microbial sampling (including those techniques able to detect the pathogen in question); cases with a pathogen determined.

Susceptibility testing was not generally recorded, with the exception of Staphylococcus aureus. Therefore, all enterobacteriaceae, Pseudomonas aeruginosa and $S$ aureus isolates were considered to be potential MDR pathogens.

\section{CRB-65 score and mortality}

The CRB-65 score consists of four variables: confusion, respiratory rate $\geq 30 / \mathrm{min}$, systolic blood pressure $<90 \mathrm{~mm} \mathrm{Hg}$ or diastolic blood pressure $\leq 60 \mathrm{~mm} \mathrm{Hg}$, and age $\geq 65$ years. One point is given for each parameter present, which results in CRB65 scores of $0-4$. For each patient the CRB-65 score was calculated with patient data assessed at first presentation.

Short-term mortality was defined as death within 30 days of diagnosis and long-term mortality as death within 180 days of diagnosis

\section{Statistical analysis}

Hospitalised patients aged $\geq 65$ years with CAP were considered to represent the current standard group and were compared with patients aged $\geq 65$ years with NHAP.

Comparisons between groups were performed by means of the $\chi^{2}$ test for categorical variables and the Student $t$ test for continuous variables (or the non-parametric Mann-Whitney U test when data were not normally distributed). All analyses were performed using SPSS software (SPSS 19.0; SPSS Inc., Chicago, IL, USA). All tests of significance were two tailed and $\alpha$ was set at 0.05 .

\section{RESULTS}

\section{Patient population}

Overall, 3087 hospitalised patients aged $\geq 65$ years were included in our analysis. Of these, 518 had NHAP.

\section{Baseline characteristics}

The following characteristics were significantly different: the NHAP group consisted of more women, had lower body mass index and fewer cases of obesity, were less frequent smokers and less frequently on long-term oxygen treatment (table 1).

Table 1 Baseline characteristics and comorbidities

\begin{tabular}{|c|c|c|c|}
\hline Variable & $\begin{array}{l}\text { Patients with } \\
\text { CAP } \geq 65 \text { years } \\
(n=2569)\end{array}$ & $\begin{array}{l}\text { Patients with } \\
\text { NHAP } \geq 65 \text { years } \\
(n=518)\end{array}$ & p Value \\
\hline $\begin{array}{l}\text { Age, years (median } \\
\text { (IQR) (n)) }\end{array}$ & $76.1(10.8)(2569)$ & $83.3(12.0)(518)$ & $<0.001$ \\
\hline Men, n (\%) & $1609(62.6)$ & $221(42.7)$ & $<0.001$ \\
\hline $\begin{array}{l}\text { Weight, kg (median } \\
\text { (IQR) (n)) }\end{array}$ & $74(20)(2488)$ & 65 (19) (423) & $<0.001$ \\
\hline $\begin{array}{l}\text { Height, cm (median } \\
\text { (IOR) (n)) }\end{array}$ & 170 (13) (2483) & $167(12)(426)$ & $<0.001$ \\
\hline $\begin{array}{l}\text { BMI, } \mathrm{kg} / \mathrm{m}^{2} \text { (median } \\
\text { (IOR) (n)) }\end{array}$ & $25.2(5.7)(2480)$ & $23.0(5.0)(420)$ & $<0.001$ \\
\hline Obesity (BMI $\geq 30), n(\%)$ & $433(17.5)$ & $31(7.4)$ & $<0.001$ \\
\hline Smoker, n (\%) & $453(18.3)$ & $40(8.9)$ & $<0.001$ \\
\hline $\begin{array}{l}\text { Pack-years (median } \\
\text { (IOR) (n)) }\end{array}$ & $30(35)(1095)$ & $30(28)(78)$ & 0.285 \\
\hline $\begin{array}{l}\text { Long-term oxygen } \\
\text { therapy, } \mathrm{n}(\%)\end{array}$ & $209(8.2)$ & $16(3.1)$ & $<0.001$ \\
\hline $\begin{array}{l}\text { Pneumococcal vaccination } \\
\text { in the past } 5 \text { years, } \mathrm{n}(\%)\end{array}$ & $389(17.1)$ & $27(9.3)$ & $<0.001$ \\
\hline Comorbidity, n (\%) & $2275(90.2)$ & $376(97.1)$ & $<0.001$ \\
\hline Chronic respiratory disease & $1197(46.8)$ & $153(30.3)$ & $<0.001$ \\
\hline Congestive heart failure & $901(35.2)$ & $265(52.1)$ & $<0.001$ \\
\hline Other heart diseases & $1376(54.0)$ & $258(51.0)$ & 0.221 \\
\hline Cerebrovascular disease & $390(15.2)$ & $336(66.1)$ & $<0.001$ \\
\hline $\begin{array}{l}\text { Other chronic neurological } \\
\text { disorder }\end{array}$ & $203(7.9)$ & $152(29.9)$ & $<0.001$ \\
\hline Renal insufficiency & $419(16.4)$ & $121(24.0)$ & $<0.001$ \\
\hline Chronic liver disease & $83(3.2)$ & $14(2.8)$ & 0.575 \\
\hline Diabetes mellitus & $726(28.3)$ & $170(33.3)$ & 0.022 \\
\hline Malignancy & $371(14.5)$ & $58(11.6)$ & 0.088 \\
\hline
\end{tabular}

BMI, body mass index; CAP, community-acquired pneumonia; NHAP, nursing-homeacquired pneumonia. 


\section{Comorbidities}

Comorbidity was very common in both groups but even more so in patients with NHAP (97.1\% vs $90.2 \%$ ). Chronic respiratory disease was less frequent whereas congestive heart failure, cerebrovascular diseases, renal diseases and diabetes mellitus were more frequent in patients with NHAP. The largest difference was in patients with cerebrovascular disease $(66.1 \%$ vs $15.2 \%$ for the NHAP and CAP groups, respectively) (table 1 ).

\section{Physical examination findings}

Cough, sputum expectoration and chest pain were less common, whereas confusion, low blood pressure and tachypnoea were more common in the NHAP group compared with the CAP group, indicating more severe pneumonia at presentation (table 2).

\section{Laboratory investigations}

The main differences related to a higher frequency of anaemia and leucocytosis, and to a higher thrombocyte count in the NHAP group. However, mean C-reactive protein (CRP) was lower (table 2).

Table 2 Initial physical examination and laboratory findings

\begin{tabular}{|c|c|c|c|}
\hline Variable & $\begin{array}{l}\text { Patients with } \\
\text { CAP } \geq 65 \text { years } \\
(\mathrm{n}=2569)\end{array}$ & $\begin{array}{l}\text { Patients with } \\
\text { NHAP } \geq 65 \text { years } \\
(n=518)\end{array}$ & p Value \\
\hline Cough, n (\%) & $2266(88.5)$ & $425(83.3)$ & \\
\hline Purulent sputum, n (\%) & $1394(54.5)$ & $210(41.3)$ & $<0.001$ \\
\hline Fever, n (\%) & 1461 (56.9) & $294(56.8)$ & 0.9 \\
\hline Dyspnoea, n (\%) & $2072(81.2)$ & $424(84.1)$ & 0.1 \\
\hline Confusion, n (\%) & $374(14.7)$ & $243(49.2)$ & $<0.0$ \\
\hline Chest pain, n (\%) & $820(33.2)$ & 65 (16.4) & $<0.00$ \\
\hline $\begin{array}{l}\text { Severe hypotension*, } \\
\text { n (\%) }\end{array}$ & $542(21.2)$ & $154(30.3)$ & $<0.001$ \\
\hline Tachycardia†, n (\%) & $885(34.7)$ & $197(38.6)$ & 0.091 \\
\hline Tachypneał, n (\%) & $310(13.0)$ & $83(17.8)$ & 0.007 \\
\hline $\begin{array}{l}\text { Haemoglobin, g/dl } \\
\text { (median (IOR) (n)) }\end{array}$ & $13.2(2.4)(2508)$ & $12.6(2.7)(507)$ & $<0.0$ \\
\hline Anaemia§, n (\%) & $892(35.6)$ & $225(44.4)$ & $<0.001$ \\
\hline $\begin{array}{l}\text { Complete blood count, } \\
\text { n (\%) }\end{array}$ & $2535(99.7)$ & $508(99.8)$ & \\
\hline With differential, n (\%) & $716(29.1)$ & $110(22.6)$ & 0.004 \\
\hline $\begin{array}{l}\text { Haematocrit, \% } \\
\text { (median (IOR) (n)) }\end{array}$ & $39.0(6.0)(2327)$ & $38.0(7.0)(474)$ & $<0.001$ \\
\hline $\begin{array}{l}\text { Platelets, } / 10^{-9} \text { litre } \\
\text { (median (IOR) (n)) }\end{array}$ & $230(123)(2491)$ & $259(143)(502)$ & $<0.001$ \\
\hline Thrombopenia $\uparrow, ~ n(\%)$ & $243(9.8)$ & $33(6.6)$ & 0.025 \\
\hline $\begin{array}{l}\text { Leucocytes, } / 10^{-9} \text { litre } \\
\text { (median (IQR) (n)) }\end{array}$ & $12.4(7.1)(2532)$ & $13.5(8.5)(507)$ & \\
\hline Leuocytosis**, n (\%) & $46(1.8)$ & $13(2.6)$ & 0.2 \\
\hline Leucopenia††, n (\%) & $33(1.3)$ & $6(1.2)$ & 0.827 \\
\hline $\begin{array}{l}\text { Lymphocytes, \% } \\
\text { (median (IQR) (n)) }\end{array}$ & $10(9)(710)$ & $8.5(8.4)(109)$ & \\
\hline $\begin{array}{l}\text { CRP, mg/litre } \\
\text { (median (IOR) (n)) }\end{array}$ & $112(180)(2478)$ & 97 (149) (492) & \\
\hline $\begin{array}{l}\text { BUN, mg/dl (median } \\
\text { (IQR) (n)) }\end{array}$ & $20.2(15.5)(2163)$ & $24.9(23.9)(454)$ & $<0.001$ \\
\hline
\end{tabular}

*Systolic $<90 \mathrm{~mm} \mathrm{Hg}$ or diastolic $\leq 60 \mathrm{~mm} \mathrm{Hg}$

† Heart rate $>100 / \mathrm{min}$.

$\ddagger$ Respiratory rate $\geq 30 / \mathrm{min}$.

$\S 12 \mathrm{~g} / \mathrm{dl}$ for women, $13 \mathrm{~g} / \mathrm{dl}$ for men.

TPlatelet count $<140 / 10^{-9}$ litre.

**Leucocytes $>30 / 10^{-9}$ litre.

$\dagger+$ Leucocytes $<4 / 10^{-9}$ litre.

BUN, blood urea nitrogen; CAP, community-acquired pneumonia; CRP, C-reactive protein; NHAP, nursing-home-acquired pneumonia.

\section{Gas exchange}

Arterial blood gas analysis was performed less frequently in patients with NHAP compared with those with CAP $(69.9 \%$ vs $78.1 \%, \mathrm{p}<0.001)$.

\section{Severity at presentation}

The time from symptom presentation to hospital attendance was around 2 days less in the NHAP group compared with the CAP group. The proportion of patients classified as CRB-65 3-4 was around threefold higher in the NHAP group. However, the rate of mechanical ventilation was similar (5.0\% vs $4.8 \%)$ (table 3).

\section{Microbial aetiology}

Diagnostic samples (package 1: blood cultures and urine antigen testing, $n=1938(80.4 \%)$ vs $n=265(63.5 \%), p<0.001$; package 2 : blood cultures and urine antigen testing plus respiratory sample, $\mathrm{n}=933(38.7 \%)$ vs $\mathrm{n}=49(11.8 \%), \mathrm{p}<0.001)$ were retrieved less frequently in the NHAP group compared with the CAP group.

The proportion of patients with a diagnostic investigation able to identify a potential MDR pathogen (methicillin-resistant $S$ aureus (MRSA), enterobacteria, $P$ aeruginosa) was significantly lower in the NHAP group ( $\mathrm{n}=2350$ vs $\mathrm{n}=382,91.4 \%$ vs $73.7 \%$, $\mathrm{p}<0.001)$.

The overall findings for microbial investigation were similar (27.7\% vs $29.7 \%$ ). S pneumoniae was the most frequent pathogen in both groups. Potential MDR pathogens such as enterobacteriaceae, $P$ aeruginosa and $S$ aureus were all very rare $(<5 \%$ for the total population and for patients with microbial sampling). There were only minor differences in pathogens, with $H$ influenzae and $M$ pneumoniae being less frequent and $S$ aureus more frequent in patients with NHAP. In the NHAP group, 11 of 12 patients with $S$ aureus had central nervous system (CNS) disorders. However, the absolute and relative frequency of $S$ aureus was minimal $(n=12,2.3 \%$ of total population, $3.1 \%$ of those with microbial sampling and $10.3 \%$ of those with a pathogen determined), and of these, only two cases were MRSA (table 4).

\section{Antimicrobial treatment}

Patients with NHAP received antimicrobial pretreatment less frequently than patients with CAP (14.5\% vs $18.9 \%)$. Monotherapy was more frequent and combination treatment less frequent in patients with NHAP $(22.8 \%$ vs $41.8 \%$ and $77.2 \%$ vs $57.2 \%$ ). In addition, more patients with NHAP received Blactams and fewer received macrolides $(91.6 \%$ vs $86.9 \%$ and $16.6 \%$ vs $38.4 \%$ ) and a change in antimicrobial treatment was

Table 3 Severity of pneumonia at admission

\begin{tabular}{|c|c|c|c|}
\hline Variable & $\begin{array}{l}\text { Patients with } \\
\text { CAP } \geq 65 \text { years } \\
(\mathrm{n}=2569)\end{array}$ & $\begin{array}{l}\text { Patients with } \\
\text { NHAP } \geq 65 \text { years } \\
(\mathrm{n}=518)\end{array}$ & p Value \\
\hline Mechanical ventilation, $\mathrm{n}(\%)$ & $123(4.8)$ & $26(5.0)$ & 0.815 \\
\hline \multicolumn{4}{|l|}{ CRB-65 score, n (\%) } \\
\hline 0 & 0 & 0 & - \\
\hline $1-2$ & 2165 (92.3) & $327(73.3)$ & $<0.001$ \\
\hline $3-4$ & $181(7.7)$ & $119(26.7)$ & $<0.001$ \\
\hline $\begin{array}{l}\text { Time from symptoms } \\
\text { until presentation, days } \\
\text { (median (IQR) (n)) }\end{array}$ & $4(5)(1513)$ & $2(4)(226)$ & $<0.001$ \\
\hline $\begin{array}{l}\text { Length of stay, days } \\
\text { (median (IQR) (n)) }\end{array}$ & $11(7)(2429)$ & $10(7)(436)$ & $<0.001$ \\
\hline
\end{tabular}

CAP, community-acquired pneumonia; CRB-65, confusion, respiratory rate, blood pressure, 65 years and older; NHAP, nursing-home-acquired pneumonia. 
Table 4 Aetiology of pneumonia

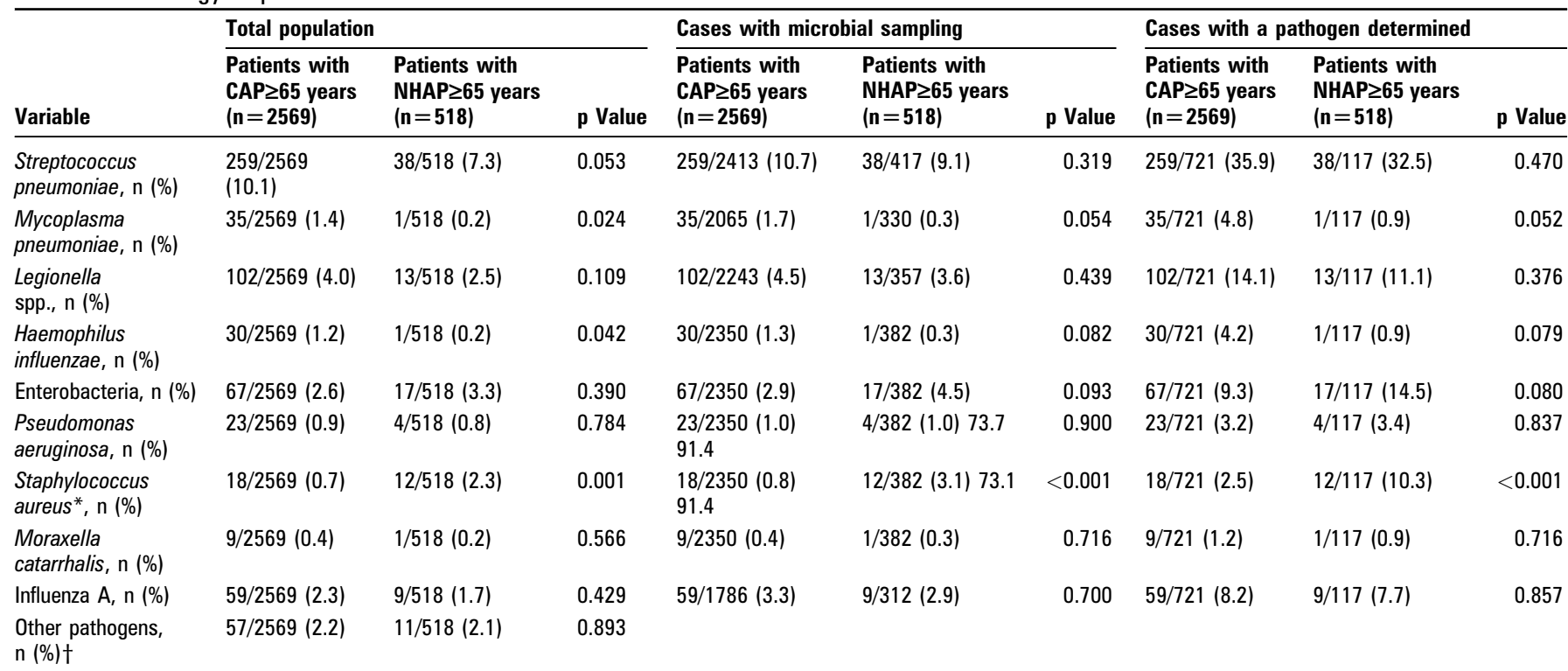

Aetiology is presented as pathogens per total population; pathogens per patients with microbial sampling; pathogens per patients with a pathogen determined. Enterobacteria comprise: Escherichia coli, Klebsiella pneumoniae, Klebsiella oxytoca, Enterobacter spp., Proteus mirabilis, Serratia marcescens, Citrobacter spp., Marganella morganii.

${ }^{*} n=2$ accounted for methicillin-resistant $S$ aureus.

†Undetermined as aetiology.

CAP, community-acquired pneumonia; NHAP, nursing-home-acquired pneumonia.

performed more frequently in patients with NHAP $(42.4 \%$ vs $36.6 \%$ ) (table 5).

\section{Outcomes}

Short-term mortality was nearly fourfold higher in the NHAP group compared with the CAP group (26.6 vs $7.2 \%$ ), and longterm mortality nearly threefold higher (43.8\% vs $14.6 \%$ ) (table 5 ).

Table 5 Initial antimicrobial treatment and outcomes

\begin{tabular}{|c|c|c|c|}
\hline Variable & $\begin{array}{l}\text { Patients with } \\
\text { CAP } \geq 65 \text { years } \\
(\mathrm{n}=2569)\end{array}$ & $\begin{array}{l}\text { Patients with } \\
\text { NHAP } \geq 65 \text { years } \\
(n=518)\end{array}$ & p Value \\
\hline Prior antibiotic therapy* $\mathrm{n}(\%)$ & $481(18.9)$ & $73(14.5)$ & 0.019 \\
\hline Initial antibiotic therapy, $\mathrm{n}(\%)$ & $2550(99.3)$ & $513(99.0)$ & 0.523 \\
\hline Monotherapy, n (\%) & $1476(57.9)$ & $396(77.2)$ & $<0.001$ \\
\hline Combination, n (\%) & $1067(41.8)$ & $117(22.8)$ & $<0.001$ \\
\hline $\begin{array}{l}\text { Duration of antibiotic } \\
\text { therapy, days (median } \\
\text { (IQR) (n)) }\end{array}$ & $10(6)(2342)$ & $10(6)(400)$ & $<0.001$ \\
\hline $\begin{array}{l}\text { Change in antibiotic } \\
\text { therapy, } \mathrm{n}(\%)\end{array}$ & $876(36.6)$ & $176(42.4)$ & 0.023 \\
\hline ß-Lactam antibiotics, n (\%) & $2216(86.9)$ & $470(91.6)$ & 0.003 \\
\hline Penicillins, n (\%) & $1258(49.3)$ & $280(54.6)$ & 0.030 \\
\hline Cephalosporins, n (\%) & $941(36.9)$ & $193(37.6)$ & 0.758 \\
\hline Carbapenems, n (\%) & $29(1.1)$ & $5(1.0)$ & 0.748 \\
\hline Macrolides, n (\%) & $980(38.4)$ & $85(16.6)$ & $<0.001$ \\
\hline Quinolones, n (\%) & $358(14.0)$ & $54(10.5)$ & 0.033 \\
\hline Tetracylines, n (\%) & $9(0.4)$ & $0(0.0)$ & 0.178 \\
\hline Glycopeptides, n (\%) & $6(0.2)$ & $0(0.0)$ & 0.271 \\
\hline Lincosamides, $\mathrm{n}(\%)$ & $15(0.6)$ & $4(0.8)$ & 0.614 \\
\hline Ketolides, n (\%) & $1(0.0)$ & $0(0.0)$ & 0.654 \\
\hline co-Trimoxazole, n (\%) & $6(0.2)$ & $2(0.4)$ & 0.531 \\
\hline Aminoglycosides, n (\%) & $8(0.3)$ & $4(0.8)$ & 0.123 \\
\hline Other antibiotics, n (\%) & $11(0.4)$ & $10(1.9)$ & $<0.001$ \\
\hline Died within 30 days, $\mathrm{n}(\%)$ & $172(7.2)$ & $105(26.6)$ & $<0.001$ \\
\hline Died within 180 days, n (\%) & $352(14.6)$ & $173(43.8)$ & $<0.001$ \\
\hline
\end{tabular}

Death rates were still very high in patients with NHAP without comorbidities, reaching $23.1 \%$ vs $2.6 \%$ for short-term mortality and $30.8 \%$ vs $6.8 \%$ for long-term mortality.

Patients receiving enteral tube feeding $(n=103,78.6 \%$ in the NHAP group) had the highest mortality rates ( $30.7 \%$ short-term and $56 \%$ long-term mortality).

Mortality rates according to aetiology in both groups are listed in table 6. Short-term mortality in patients with CAP aged $\geq 65$ years was between $3.4 \%$ and $12.5 \%$, with the highest rates for $S$ aureus, enterobacteriaceae, $P$ aeruginosa and influenza A whereas it was threefold to fourfold higher for all leading pathogens in patients with NHAP. Similar rates were obvious in long-term mortality, with $S$ aureus being associated with an extremely high mortality rate (80\%).

\section{DISCUSSION}

The most important findings of this study were the following: patients with NHAP presented with more severe pneumonia but received the same frequency of mechanical ventilation and less antimicrobial combination treatment; there were no clinically relevant differences in aetiology and potential MDR pathogens were very rare $(<5 \%)$; short-term and long-term mortality for NHAP was about fourfold and threefold higher than for CAP in patients aged $\geq 65$ years, however excess mortality was a general pattern and not related to MDR pathogens.

Our approach to limit the comparison of patients to those aged $\geq 65$ years is an important methodological decision. In a previous study from the CAPNETZ group comparing patients aged $<65$ years and $\geq 65$ years, those with NHAP showed a fourfold increased mortality rate and an increased rate of gramnegative bacillary infections compared with patients living in the community $(7.1 \%$ vs $3.7 \%$, expressed as rate of pathogens per cases with pathogens identified). ${ }^{21}$ This difference, however, is mainly a result of inflation by including a significant number of younger patients. In view of the fundamentally different epidemiology and prognosis of patients $<65$ years, ${ }^{18}$ we argue that the characteristics of NHAP can be assessed more 
Table 6 Short-term and long-term mortality according to underlying aetiologies

\begin{tabular}{|c|c|c|c|c|c|c|}
\hline \multirow[b]{2}{*}{ Pathogen } & \multicolumn{2}{|c|}{ Short-term mortality } & \multirow[b]{2}{*}{ p Value } & \multicolumn{2}{|c|}{ Long-term mortality } & \multirow[b]{2}{*}{ p Value } \\
\hline & $\begin{array}{l}\text { Patients with } \\
\text { CAP } \geq 65 \text { years } \\
(\mathrm{n}=2569)\end{array}$ & $\begin{array}{l}\text { Patients with } \\
\text { NHAP } \geq 65 \text { years } \\
(n=518)\end{array}$ & & $\begin{array}{l}\text { Patients with } \\
\text { CAP } \geq 65 \text { years } \\
(\mathrm{n}=2569)\end{array}$ & $\begin{array}{l}\text { Patients with } \\
\text { NHAP } \geq 65 \text { years } \\
(n=518)\end{array}$ & \\
\hline Mycoplasma pneumonia, n (\%) & $2 / 34(5.9)$ & $0 / 0$ & NC & $5 / 34(14.7)$ & $0 / 0$ & NC \\
\hline Legionella spp., n (\%) & $5 / 95(5.3)$ & $2 / 12(16.7)$ & 0.132 & $13 / 95(13.7)$ & $4 / 12(33.3)$ & 0.079 \\
\hline Haemophilus influenza, $\mathrm{n}(\%)$ & $1 / 29(3.4)$ & $0 / 1(0.0)$ & 0.850 & $1 / 29(3.4)$ & $0 / 1(0.0)$ & 0.850 \\
\hline Staphylococcus aureus ${ }^{*}, \mathrm{n}(\%)$ & $2 / 17(11.8)$ & $4 / 10(40.0)$ & 0.088 & $6 / 17(35.3)$ & $8 / 10(80.0)$ & 0.025 \\
\hline Moraxella catarrhalis, n (\%) & $1 / 8(12.5)$ & $0 / 1(0.0)$ & 0.708 & $2 / 8(25.0)$ & $1 / 1(100.0)$ & 0.134 \\
\hline Influenza A, n (\%) & $5 / 55(9.1)$ & $1 / 8(12.5)$ & 0.759 & $6 / 55(10.9)$ & $2 / 8(25.0)$ & 0.263 \\
\hline
\end{tabular}

${ }^{*} \mathrm{n}=1$ accounted for methicillin-resistant $S$ aureus

CAP, community-acquired pneumonia; NC, not calculable; NHAP, nursing-home-acquired pneumonia.

effectively by restricting the comparator to patients with CAP aged $\geq 65$ years. To avoid the impact of age, patients with NHAP were also restricted to those aged $\geq 65$ years.

Patients with NHAP were a clinically distinct group compared with those aged $\geq 65$ years. They had a mean age of over 80 years, more frequently had congestive heart failure, cerebrovascular disease, renal disease and diabetes mellitus, indicating that cardiovascular and neurological morbidity was the primary underlying condition. Although these patients presented more quickly after developing symptoms, initial pneumonia severity was clearly higher according to symptoms at presentation and CRB-65 scoring. Nevertheless, they obviously received less attention and initial antimicrobial treatment was not as intensive: blood gas analysis was performed around 10\% less frequently and antimicrobial combination treatment was administered in only half of cases compared with patients without NHAP. In addition, despite higher severity according to CRB-65 scoring and the presence of severe hypotension, mechanical ventilation was not given more frequently. However, short-term and long-term mortality was far higher. All these observations clearly show treatment restrictions due to advanced age and severe disabling conditions in a significant number of patients with NHAP. Unfortunately, we did not record data on 'do not resuscitate' (DNR) orders. However, although DNR orders are one form of treatment restriction, other hidden restrictions (such as 'do not re-evaluate extensively in case of treatment failure', 'do not transfer to ICU [intensive care unit]', 'do not ventilate' etc) are usually not recorded. Therefore, we argue that even recording DNR orders actually underestimates the rate of treatment restrictions. We could not identify clinically relevant differences in aetiologic patterns or a clinically relevant higher frequency of potential MDR pathogens. In addition, mortality rates according to pathogens clearly show that there is a threefold to fourfold higher mortality for NHAP across all leading pathogens. This is strong evidence against the hypothesis that excess mortality is related to inadequate treatment because of potential MDR pathogens not covered by empirical treatment for CAP. Instead, as described by others, MDR pathogens might be associated with severe disablity. ${ }^{22}$ Thus, the aetiologic patterns identified do not account for the short-term and long-term excess mortality observed in patients with NHAP.

We found that most cases of pneumonia caused by $S$ aureus had CNS comorbidity, and that $S$ aureus was associated with the highest mortality. This is explained by the known risk for pneumonia through $S$ aureus in patients with CNS disorders, mainly driven by aspiration. ${ }^{23} 24$ Thus, a careful individual assessment of risk for specific pathogens is clearly indicated in every patient with NHAP.

For long-term mortality, an interesting observation was a lower mean CRP value in patients with NHAP. Lower CRP values have recently been identified as an independent predictor of long-term mortality. This probably reflects failure to mount a sufficient immune response. ${ }^{25}$

Our results are in line with two other important European studies. In a British 18-month prospective cohort study of 437 patients admitted to hospital with CAP, 40 (9\%) came from nursing homes. Analysis of this small series yielded nearly identical results to our study. Patients with NHAP were less likely to have a productive cough or pleuritic pain but they were more likely to be confused and had more severe disease. Inhospital mortality was extremely high $(53 \%$ vs $13 \%$ in patients with CAP). S pneumoniae was the most common pathogen $(55 \%$ NHAP, 43\% CAP). Atypical pathogens, enterobacteriaceae and $S$ aureus were uncommon. Poor functional status accounted for the increased mortality in NHAP. ${ }^{11}$ More recently, a Spanish study including 150 consecutive cases of NHAP over a 10-year period showed clinical characteristics comparable to those with hospital-acquired pneumonia. However, microbial patterns and mortality data of patients with NHAP were more similar to those with CAP. Potential MDR pathogens were rare, accounting for only $7 \%$ of pathogens. ${ }^{12}$ Two recent studies from Spain and the UK on HCAP confirmed this observation for both NHAP and HCAP. 2627

Likewise, the main findings of two Canadian studies were very similar, including comorbidity patterns (more CNS disease, fewer smokers and less pulmonary disease), less $H$ influenzae, high mortality, and differences in treatment (less macrolide treatment). ${ }^{10}$ Mortality was very high but functional status rather than different pathogen patterns was the main predictor of death. ${ }^{10} 28$ There was also clear evidence for treatment restrictions. ${ }^{28}$

Some US data indicate a different microbial pattern in patients with NHAP. For example, El Solh et al found 17 of 88 (19\%) pathogens of patients with NHAP and severe pneumonia were MDR pathogens ${ }^{21}$; in another study, the authors found anaerobic organisms more often in patients with NHAP and empyema. ${ }^{29}$ However, this seems to reflect a general trend in older people rather than a specific finding in patients with NHAP. Kaplan et al reported extremely high rates of enterobacteriaceae and P aeruginosa in a large population of patients aged $\geq 65$ years. $^{2}$ Accordingly, Koleff et al ${ }^{13}$ listed exceedingly high rates of MDR pathogens in patients with HCAP (including many with NHAP) but also (to a lesser but still unusually high 
extent) in patients with CAP. The latter finding in particular casts doubt on the validity of the microbiological investigation in this study. Finally, it could not be shown that adhering to guideline recommendations for treating patients with HCAP improved outcomes compared with those for CAP. ${ }^{30} 31$

Taken together, our data and the data reported in the literature so far show that there is no convincing evidence to support generally administering broad spectrum antimicrobial combination treatments comparable to those used for hospitalacquired pneumonia to all patients with NHAP. Instead, the initial antimicrobial coverage may still follow that recommended in CAP guidelines after assessment of specific risk factors for MDR on an individual basis. CNS disorders may particularly be addressed since they predispose people to pneumonia through $S$ aureus. Moreover, in patients with NHAP, one cannot overestimate the importance of continuous careful prognostic estimations and ethical decisions on treatment aims and possible restrictions based primarily on patients' preferences.

The strengths of this study include the multicentre prospective design over 8 years, which to the best of our knowledge is unique in the literature. In addition, our population is one of the largest reported in the literature so far. Nevertheless, some potential limitations must be addressed. First, the proportion of patients with an aetiology identified was low and did not exceed $30 \%$. The proportion of samples from which a MDR pathogen could be identified was significantly lower in patients with HCAP, resulting in potential sampling bias. We tried to overcome this limitation by reporting pathogen patterns according to three different denominators. In particular, the rate of 'pathogens per cases with microbial sampling', reflecting the likelihood of identifying the pathogen, allows us to estimate the true incidence more accurately. This rate did not result in different pathogen patterns. Thus, a systematic bias could only result from a general failure to investigate specific groups of patients at high risk of MDR pathogens not reflected in our general pattern. Although this cannot be categorically excluded in a potentially under-diagnosed population like those with NHAP, it is highly improbable that patients with such severe disabilities would have been subject to every treatment effort. Second, the CAPNETZ population may include too few patients with severe pneumonia. Therefore, the microbial patterns presented here must be viewed with caution when patients with HCAP are treated for severe pneumonia. Third, we did not assess aspiration, which has been described as an important aetiology in patients with NHAP and HCAP. However, the exact implications of aspiration in terms of microbial pathogens remain unresolved. ${ }^{22} 32$ Fourth, we did not directly measure functional status. We recorded enteral tube feeding (ETF) as a surrogate, and in fact, $78 \%$ of patients with ETF were patients with NHAP and $15.6 \%$ of patients with NHAP had ETF. Direct comparisons of mortality with other studies, however, should only be made with caution. Evidently, we ignore the external validity of these data for countries other than Germany. However, no country should regard NHAP as a condition requiring an antimicrobial treatment different from CAP prior to clear evidence that an observed excess mortality is actually related to treatment failures in the presence of potential MDR pathogens. As a note of caution, nursing homes that have patients with NHAP should invariably be regarded individually for their potential to carry a risk for the MDR pathogens.

In conclusion, the high excess mortality in our population could not be attributed to a microbial pattern different from that of CAP (including an increased incidence of potential MDR pathogens) but is likely to be a result of comorbidity and management decisions as a result of pneumonia being regarded as a terminal event related to advanced age and poor functional status. The main challenges in the treatment of patients with NHAP include a careful assessment of individual risk factors for specific pathogens and a careful continuous estimation of prognosis and patients' preferences to set appropriate treatment aims initially and during the course of the disease.

Acknowledgements We thank Dr Mark Woodhead for his help in editing the manuscript.

Funding Bundesministerium für Bildung und Forschung (BMBF).

\section{Competing interests None.}

Ethics approval Central and local ethical committees (UIm and local CAPNETZ centres).

Contributors All authors contributed to the manuscript. Santiago Ewig was leader of a local centre (Bonn, Bochum), analysed the data and revised the manuscript. Benjamin Klapdor analysed the data and wrote the manuscript. Mathias Pletz analysed the data. Gernot Rohde was leader of a local centre (Bochum) and analysed the data. Hartmut Schütte analysed the data. Tom Schaberg was leader of a local centre (Rotenburg) and analysed the data. Torsten Bauer was leader of a local centre (Berlin) and analysed the data. Tobias Welte is head of CAPNETZ, was leader of a local centre (Hannover), and analysed the data.

Provenance and peer review Not commissioned; externally peer reviewed.

\section{REFERENCES}

1. Ewig S, Birkner N, Strauss R, et al. New perspectives on community-acquired pneumonia in 388406 patients. Results from a nationwide mandatory performance measurement programme in healthcare quality. Thorax 2009;64:1062-9.

2. Kaplan V, Angus DC, Griffin MF, et al. Hospitalized community-acquired pneumonia in the elderly: age- and sex-related patterns of care and outcome in the United States. Am J Respir Crit Care Med 2002;165:766-72.

3. Venkatesan $\mathbf{P}$, Gladman J, Macfarlane JT, et al. A hospital study of community acquired pneumonia in the elderly. Thorax 1990;45:254-9.

4. Carr B, Walsh JB, Coakley D, et al. Prospective hospital study of community acquired lower respiratory tract infection in the elderly. Respir Med 1991;85:185-7.

5. Riquelme R, Torres A, El-Ebiary M, et al. Community-acquired pneumonia in the elderly: a multivariate analysis of risk and prognostic factors. Am J Respir Crit Care Med 1996;154:1450-5

6. Riquelme R, Torres A, el-Ebiary $M$, et al. Community-acquired pneumonia in the elderly. Clinical and nutritional aspects. Am J Respir Crit Care Med 1997;156:1908-14

7. Lieberman D, Lieberman D, Schlaeffer F, et al. Community-acquired pneumonia in old age: a prospective study of 91 patients admitted from home. Age Ageing 1997;26:69-75.

8. Marrie TJ. Community-acquired pneumonia in the elderly. Clin Infect Dis 2000;31:1066-78.

9. Fernández-Sabé $\mathbf{N}$, Carratalà J, Rosón B, et al. Community-acquired pneumonia in very elderly patients: causative organisms, clinical characteristics, and outcomes. Medicine 2003;82:159-69.

10. Marrie TJ, Durant H, Kwan C. Nursing home-acquired pneumonia. A case-control study. J Am Geriatr Soc 1986;34:697-702.

11. Lim WS, Macfarlane JT. A prospective comparison of nursing home acquired pneumonia with community acquired pneumonia. Eur Respir J 2001:18:362-8.

12. Polverino E, Dambrava P, Cillóniz $C$, et al. Nursing home-acquired pneumonia: a 10 year single-centre experience. Thorax 2010;65:354-9.

13. Kollef MH, Shorr A, Tabak YP, et al. Epidemiology and outcomes of health-careassociated pneumonia: results from a large US database of culture-positive pneumonia. Chest 2005;128:3854-62.

14. American Thoracic Society, Infectious Diseases Society of America. Guidelines for the management of adults with hospital-acquired, ventilatorassociated, and healthcare-associated pneumonia. Am J Respir Crit Care Med 2005; 171:388-416

15. Arancibia F, Bauer TT, Ewig $S$, et al. Community-acquired pneumonia due to gramnegative bacteria and Pseudomonas aeruginosa: incidence, risk, and prognosis. Arch Intern Med 2002;162:1849-58.

16. Ewig S, Welte T, Chastre J, et al. Rethinking the concepts of community-acquired and health-care-associated pneumonia. Lancet Infect Dis 2010;10:279-87.

17. Klapdor B, Ewig S, Pletz MW, et al; and the CAPNETZ study group: Communityacquired pneumonia in the younger is an entity of its own. 2011; (submitted).

18. Welte T, Suttorp N, Marre R. CAPNETZ-community-acquired pneumonia competence network. Infection 2004;32:234-8.

19. von Baum H, Welte T, Marre R, et al. Mycoplasma pneumoniae pneumonia revisited within the German Competence Network for Community-acquired pneumonia (CAPNETZ). BMC Infect Dis 2009;9:62. 
20. Mauch H, Lütticken R, Gatermann S, eds. Mi0 7 und 8. Infektionen der tiefen Atemwege. Teil I und II. Qualitätsstandards in der mikrobiologisch-infektiologischen Diagnostik. [Infection of the Deep Airways. Part I and II. Quality Standards in the Microbiological Diagnosis of Infectious Diseases]. Jena: Gustav-Fischer Verlag, 1999.

21. Kothe H, Bauer T, Marre R, et al; Competence Network for Community-Acquired Pneumonia study group. Outcome of community-acquired pneumonia: influence of age, residence status and antimicrobial treatment. Eur Respir J 2008;32:139-46.

22. El Solh AA, Pietrantoni C, Bhat A, et al. Indicators of potentially drug-resistant bacteria in severe nursing home-acquired pneumonia. Clin Infect Dis 2004;39:474-80.

23. Rello J, Ausina V, Ricart M, et al. Nosocomial pneumonia in critically ill comatose patients: need for a differential therapeutic approach. Eur Respir J 1992:5:1249-53

24. Ewig S, Torres A, El-Ebiary M, et al. Bacterial colonization patterns in mechanically ventilated patients with traumatic and medical head injury. Incidence, risk factors, and association with ventilator-associated pneumonia. Am J Respir Crit Care Med 1999:159:188-98.

25. Guertler C, Wirz B, Christ-Crain M, et al. Inflammatory responses predict long-term mortality risk in community-acquired pneumonia. Eur Respir J 2011;37:1439-46.
26. Garcia-Vidal C, Viasus D, Roset A, et al. Low incidence of multidrug-resistant organisms in patients with healthcare-associated pneumonia requiring hospitalization. Clin Microbiol Infect 2011;17:1659-65.

27. Chalmers JD, Taylor JK, Singanayagam A, et al. Epidemiology, antibiotic therapy, and clinical outcomes in health care-associated pneumonia: a UK cohort study. Clin Infect Dis 2011:53:107-13.

28. Marrie TJ, Blanchard W. A comparison of nursing home-acquired pneumonia patients with patients with community-acquired pneumonia and nursing home patients without pneumonia. J Am Geriatr Soc 1997:45:50-5.

29. El Solh AA, Alhajjhasan A, Ramadan FH, et al. A comparative study of communityand nursing home-acquired empyema thoracis. J Am Geriatr Soc 2007:55:1847-52

30. El Solh AA, Akinnusi ME, Alfarah Z, et al. Effect of antibiotic guidelines on outcomes of hospitalized patients with nursing home-acquired pneumonia. J Am Geriatr Soc 2009; $\mathbf{5 7}: 1030-5$

31. Attridge RT, Frei CR, Restrepo $\mathrm{Ml}$, et al. Guideline-concordant therapy and outcomes in healthcare-associated pneumonia. Eur Respir J 2011;38:878-87.

32. Carratalà J, Mykietiuk A, Fernández-Sabé N, et al. Health care-associated pneumonia requiring hospital admission: epidemiology, antibiotic therapy, and clinical outcomes. Arch Intern Med 2007;167:1393-9.

\section{Journal club}

\section{Improved survival in cystic fibrosis patients with severely impaired lung function}

A forced expiratory volume in one second $\left(\mathrm{FEV}_{1}\right)$ less than $30 \%$ predicted has been accepted as the threshold at which $50 \%$ of patients with cystic fibrosis (CF) survive 2 years or less. However, this estimate, made in the early 1990s, does not take into account recent developments in treatment. This cohort study aimed to re-evaluate the survival of CF patients with severely impaired lung function.

Two hundred and seventy-six CF patients whose $\mathrm{FEV}_{1}$ was first observed to be less than 30\% predicted between 1990 and 2003 were included in the cohort. The patients were followed up in 2-year subcohorts until 2007 and their survival was assessed. The authors showed an important improvement in the average survival of CF patients with severely impaired lung function. Median survival for patients who entered the cohort most recently (2002-2003) was 5.3 years, more than four times that for those who entered the study in the early 1990s, when median survival was 1.2 years. The authors observed a clear stepwise improvement in survival from 1994 to 1997. This was concurrent with the introduction of nebulised recombinant human DNase. A steady improvement in nutritional status also occurred in the time period studied, and an increased risk of death was associated with a body mass index below $19 \mathrm{~kg} / \mathrm{m}^{2}$.

The survival of patients with $\mathrm{CF}$ and an $\mathrm{FEV}_{1}$ less than $30 \%$ predicted has improved markedly over the last two decades, with a median predicted survival of 5.3 years.

George PM, Banya W, Pareek N, et al. Improved survival at low lung function in cystic fibrosis: cohort study from 1990 to 2007. BMJ 2011:342:1008.

\section{Vishal Narwani}

Correspondence to Vishal Narwani, Medical student, Royal Free Hospital, Pond Street, London NW3 20G, UK: vishal.narwani.10@ucl.ac.uk

Published Online First 4 May 2011

Thorax 2012;67:138. doi:10.1136/thoraxjnl-2011-200357 